\title{
Captive Breeding of Some Endemic Ornamental Fish Species in Sri Lanka
}

\author{
H.M.P. KITHSIRI*, P.P.G.S.N. SIRIWARDENA AND G.R. HEMALEE \\ RUPIKA \\ National Aquatic Resources Research and Development Agency \\ Crow Island, Colombo 15, Sri Lanka
}

*Corresponding author: E.mail: palitha_kithsiri@hotmail.com

\begin{abstract}
There is a high export demand for some endemic fish species in the ornamental fish trade in Sri Lanka. Many endemic ornamental fish species are reported to be in decline and some have become endangered due to a combination of several factors including overexploitation, aquatic pollution, and habitat modifications. Some of the endemic fish species in Sri Lanka are listed as either restricted or prohibited species for export. Present study reports preliminary results of a series of investigations on the factors affecting the breeding and fry rearing of some high demanded endemic fish species in captivity for the purpose of domestication of a broodstock.

Eight endemic fish species namely Malpulutta kretseri, Belontia signata, Danio pathirana, Rasbora vaterifloris, Puntius cumingii, Puntius srilankensis, Puntius titteya and Puntius nigrofasciatus were used for the present study. Fish were kept in $150 \mathrm{~cm} \times 90 \mathrm{~cm} \times 75 \mathrm{~cm}$ cement tanks with water to a depth of $60 \mathrm{~cm}$ and provided a breeding environment using aquatic plants and pebbles. Tank environment was monitored daily for water temperature, $\mathrm{pH}$ and dissolved oxygen content, weekly for unionized ammonia, nitrite and fortnightly for alkalinity and hardness. All the fish were fed with live feed such as Moina, mosquito laryae and microworms and pelleted feed.

Though the most of the endemic fish live in waters with a $\mathrm{pH}$ ranging from 5 to 7 , and hardness and alkalinity ranging from $40 \mathrm{mg} \mathrm{l}^{-1}$ to $120 \mathrm{mg} \mathrm{l}^{-1}$, it was found that all eight species used in the present study could be bred in captivity in waters with $\mathrm{pH}$ ranging from 7.5 to 9 , alkalinity ranging from $26 \mathrm{mg} \mathrm{l}^{-1}$ to $67.2 \mathrm{mg} \mathrm{I}^{-1}$ and hardness ranging from $36.8 \mathrm{mg} \mathrm{l}^{-1}$ to $66.4 \mathrm{mg} \mathrm{l}^{-1}$. Survival rates of fish fry were $75 \%$ $92 \%$ for all fish species except in Malpulutta kretseri, which had a survival rate of $41 \%$.
\end{abstract}

\section{Introduction}

The omamental fish industry in Sri Lanka exports marine, brackish water and freshwater fish, which are collected from the wild and bred in hatcheries. Hatchery breeding that has been developed by exporters for some species of 
freshwater fish, such as Puntius titteya and Puntius nigrofasciatus, appears to be an ideal solution to mitigate environmental impacts caused due to this trade. In the freshwater environments of Sri Lanka, there are 80 species of indigenous fish, of which 32 are endemic. A total of 60 species of fresh water fish, including 20 endemic species, are presently collected from wild to be exported in the aquarium trade. Among the most popular species in the export omamental fish industry species for exports are the endemics such as Puntius nigrofasciatus, Puntius titteya, Belontia signata, Puntius cumingii and Rasbora veterifloris. The morphology and distribution of these species are well documented by Pethiyagoda (1991). These are also considered as threatened or highly threatened species in the national context (IUCN 2000). Furthermore, all these species other than Puntius srilankensis are considered as globally threatened species, Danio pathirana is included in critically endangered category and the others in the lower risk conservation dependant category (IUCN 2000). The factors which adversely affect these species include deforestation, colonization by people, biological and chemical pollution of their natural environment and overexploitation for aquarium trade (Pethiyagoda 1991, Wijeyaratne 1993). Most of the fish that have a high demand for export are either in the restricted list or prohibited list for export according to the regulations imposed by the Department of Fisheries (Government gazette 1998). Therefore, it has become extremely necessary to study the factors affecting the captive breeding and rearing of fish fry of endemic omamental fish species with a view of domestication of broodstock.

\section{Materials and Methods}

Eight fish species namely, Belontia signata, Rasbora vaterifloris, Puntius cumingii, Puntius titteya, Puntius nigrofasciatus, Puntius srilankensis, Malpulutta kretseri, and Danio pathirana were used for this study.

Fish were collected from the natural environment and transported to the laboratories of the National Aquatic Resources Research and Development Agency in oxygen saturated water. They were reared up to maturity in cement tanks. The breeding experiments were carried out in cement tanks measuring $150 \mathrm{~cm} \times 90 \mathrm{~cm} \times$ $75 \mathrm{~cm}$. The depth of water in the experimental tanks was $60 \mathrm{~cm}$. About $1 / 3$ of the water surface was covered with aquatic plants such as Eichhomia crassipes, Echinodorus amazonicus, Pistia stratiotis, Aponogeton sp, Valisneria sp and Hydrocotile sp. Pebbles were also introduced to the tanks to provide the natural environment as much as possible. Plants provide a substrate for the attachment of eggs and shelter for fish fry. Prior to the introduction of fish, aquatic plants were treated with a solution of alum ( 1 table spoon of alum in 1 liter of water) to prevent introduction of parasites. Before introducing plants and fish, water was conditioned for one day with aeration to remove chlorine. For the bubble nest builders, namely Belonita signata, and Malpulutta kretseri, a piece of styrofoam sheet was provided to construct the bubble nest. 
Captive breeding of endemic fish species

Healthy mature male and female fish of each species were selected using their colour and external characters and introduced into separate breeding tanks with the sex ratios given in Table 1. Each tank was observed in the moming for small fish fry since the eggs could not be observed among the plants. Temperature, $\mathrm{pH}$ ( $\mathrm{pH}$ meter model Jenway 3051) and dissolved oxygen (Dissolved oxygen meter model Extech) content in the water were monitored daily and the ammonia and nitrite contents were measured weekly using the methods described in APHA (1998). Alkalinity and hardness were measured fortnightly using titrimetric methods described in APHA (1998). The fish were fed with Moina, mosquito larvae and bread worm and the formulated feed. Fish were fed twice a day. The percentages of protein, fat, fiber and ash content in the pelleted feed used were $42 \%, 10 \%, 4 \%$, and $12 \%$ respectively. Water in the tanks ( $10 \%$ ) was changed daily, the unconsumed food and waste were siphoned out and the tanks were refilled with dechlorinated water. Tanks were not aerated during the study period. Dead plants and plant material were also removed daily and new plants were introduced accordingly. Fish were not given the hormonal treatment for induced breeding. After each breeding all fry were removed and stocked in separate fry rearing tank measured $3 \times 3 \mathrm{~m}^{2}$. Survival rate was calculated using the pooled data at the end of the 5 months study period.

\section{Results}

During the study period, the water temperature ranged between $25.2^{\circ} \mathrm{C}$ and $30.6^{\circ} \mathrm{C}$. The dissolved oxygen content was above $5 \mathrm{mg} \mathrm{l}^{-1}$ in all tanks. The $\mathrm{pH}$ values in tanks ranged between 7.4 and 9.5 (Fig. 1). The unionized ammonia and nitrite contents were below the toxic limits throughout the culture period (Fig. 2). Alkalinity and hardness values were within the acceptable limits for fresh water fish culture (Fig. 3). The number of fish used for breeding, sex ratio, number of fry observed and the breeding interval are given in Table 1. Percentage survival ranged from $75 \%$ to $91.5 \%$ for all species except Malpulutta kretseri which had survival rate of $41 \%$.

It was revealed from the results that the time interval between two successive breedings were prolonged except in the case of Malpulutta kretseri and Puntius nigrofasciatus. Impressive results were not obtained in producing attractive number of fry. Mean number of fry received was the highest in Danio pathirana and the lowest was recorded in Malpulutia kretseri. 
HM.P. Kithsiri et al.

\begin{tabular}{|c|c|c|c|c|c|c|}
\hline & 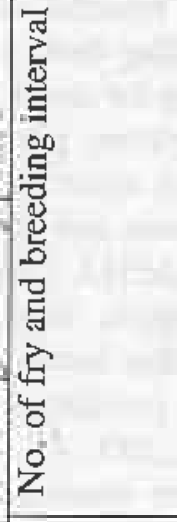 & 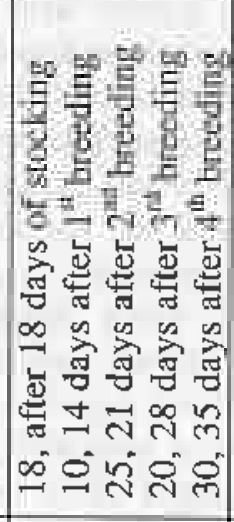 & 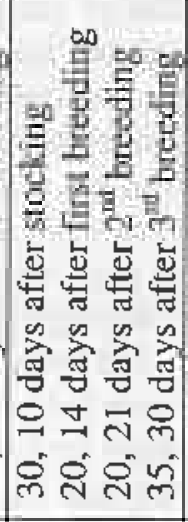 & 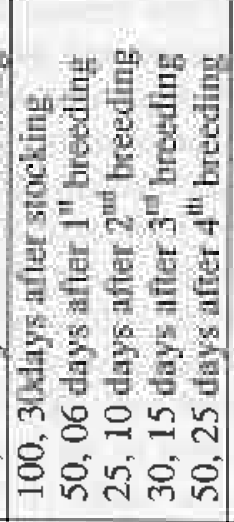 & 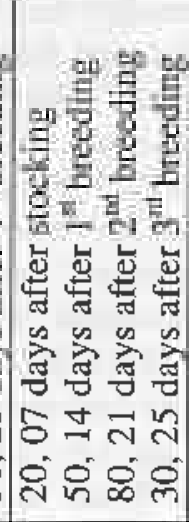 & 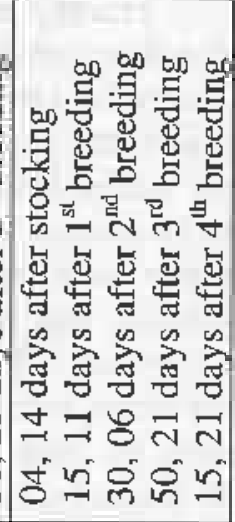 \\
\hline & 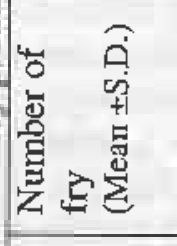 & 志 & 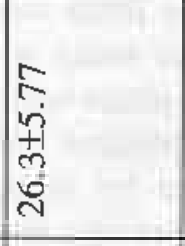 & $\begin{array}{l}8 \\
8 \\
8 \\
4 \\
0 \\
0 \\
\text { in }\end{array}$ & $\begin{array}{l}0 \\
5 \\
5 \\
1 \\
0 \\
5 \\
5\end{array}$ & $\begin{array}{l}2 \\
2 \\
0 \\
+1 \\
\infty \\
d\end{array}$ \\
\hline & 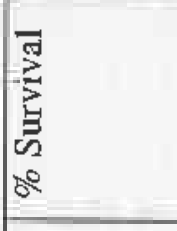 & $\mathscr{\infty}$ & 2 & 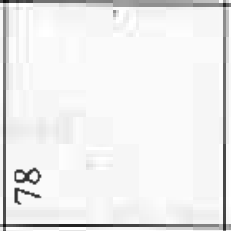 & 10 & $\infty$ \\
\hline & 电惫覀 & $\ddot{ت}$ & $ت$ & 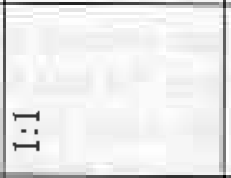 & $\ddot{z}$ & $\begin{array}{l}\stackrel{y}{m} \\
\dot{m}\end{array}$ \\
\hline & 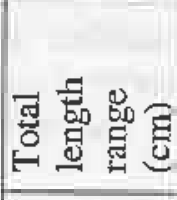 & $\begin{array}{l}0 \\
\infty \\
0 \\
0 \\
2\end{array}$ & 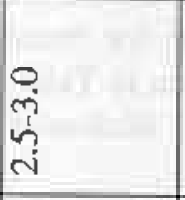 & 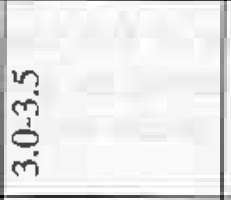 & $\begin{array}{l}n \\
r \\
i n \\
i n\end{array}$ & $\begin{array}{l}0 \\
\dot{y} \\
\dot{y} \\
\dot{r}\end{array}$ \\
\hline & 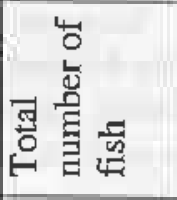 & 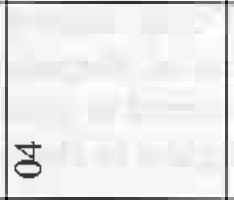 & $g$ & $\mathscr{1}$ & 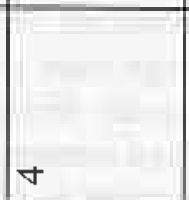 & $\varrho$ \\
\hline & 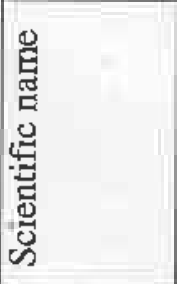 & 㻤 & 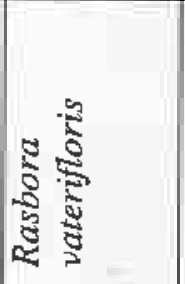 & 胥 & 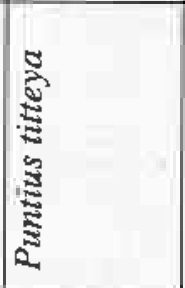 & 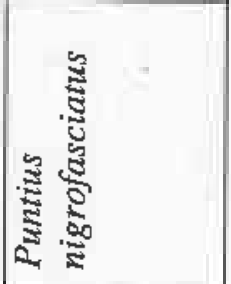 \\
\hline
\end{tabular}


Captive breeding of endemic fish species

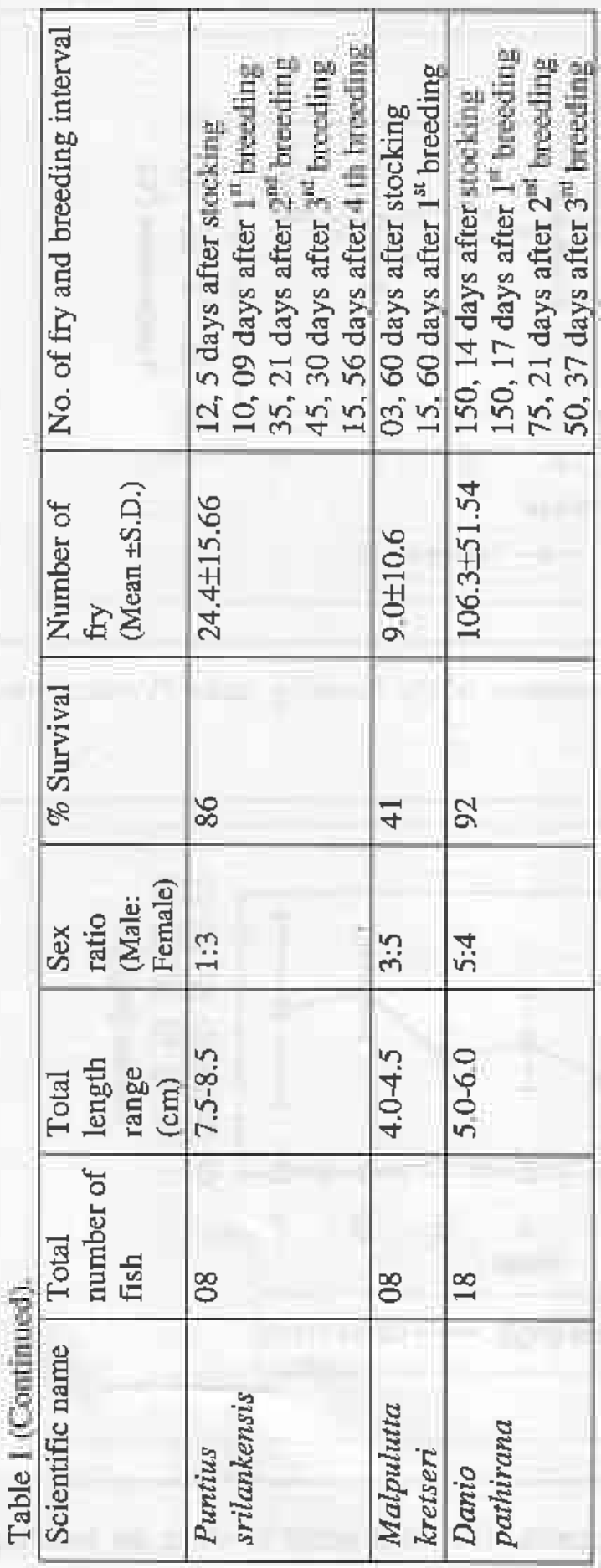




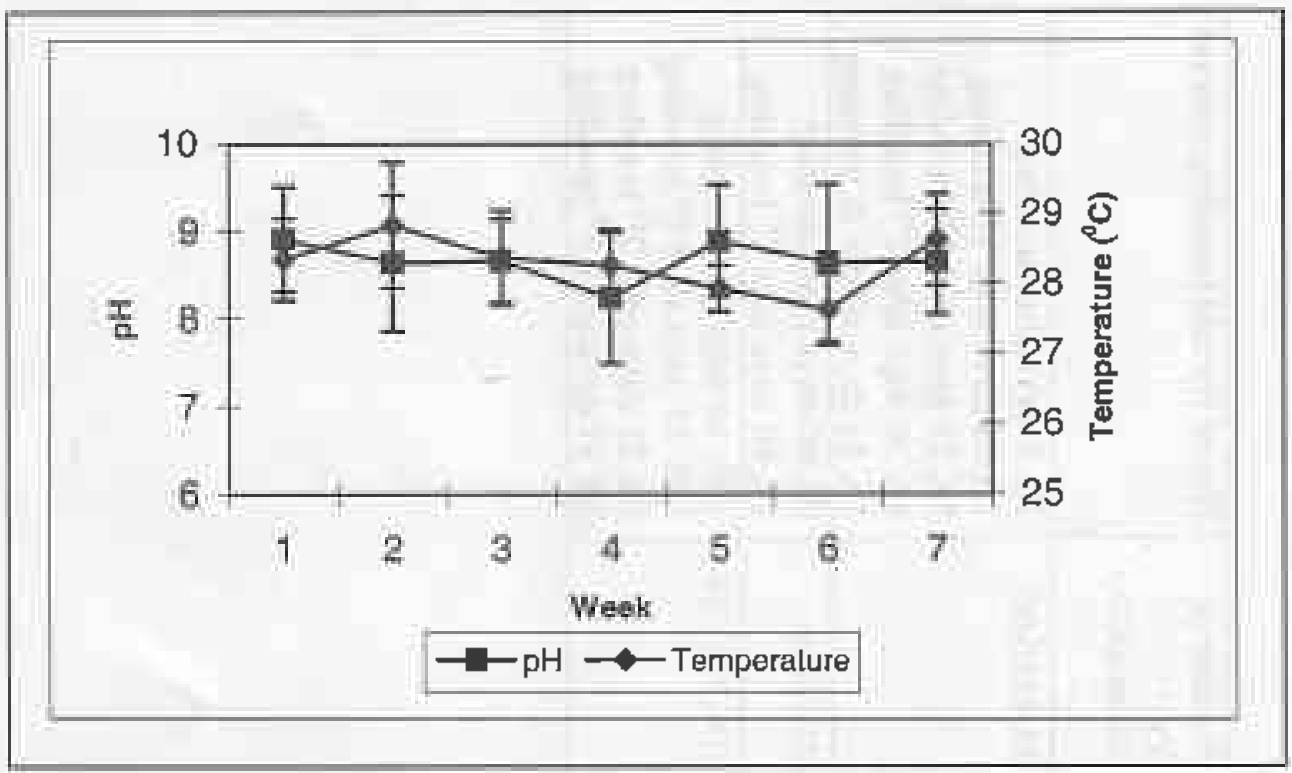

Figure 1. Variation of $\mathrm{pH}$ and temperature in the breeding tanks (Vertical bars indicate standard deviation).

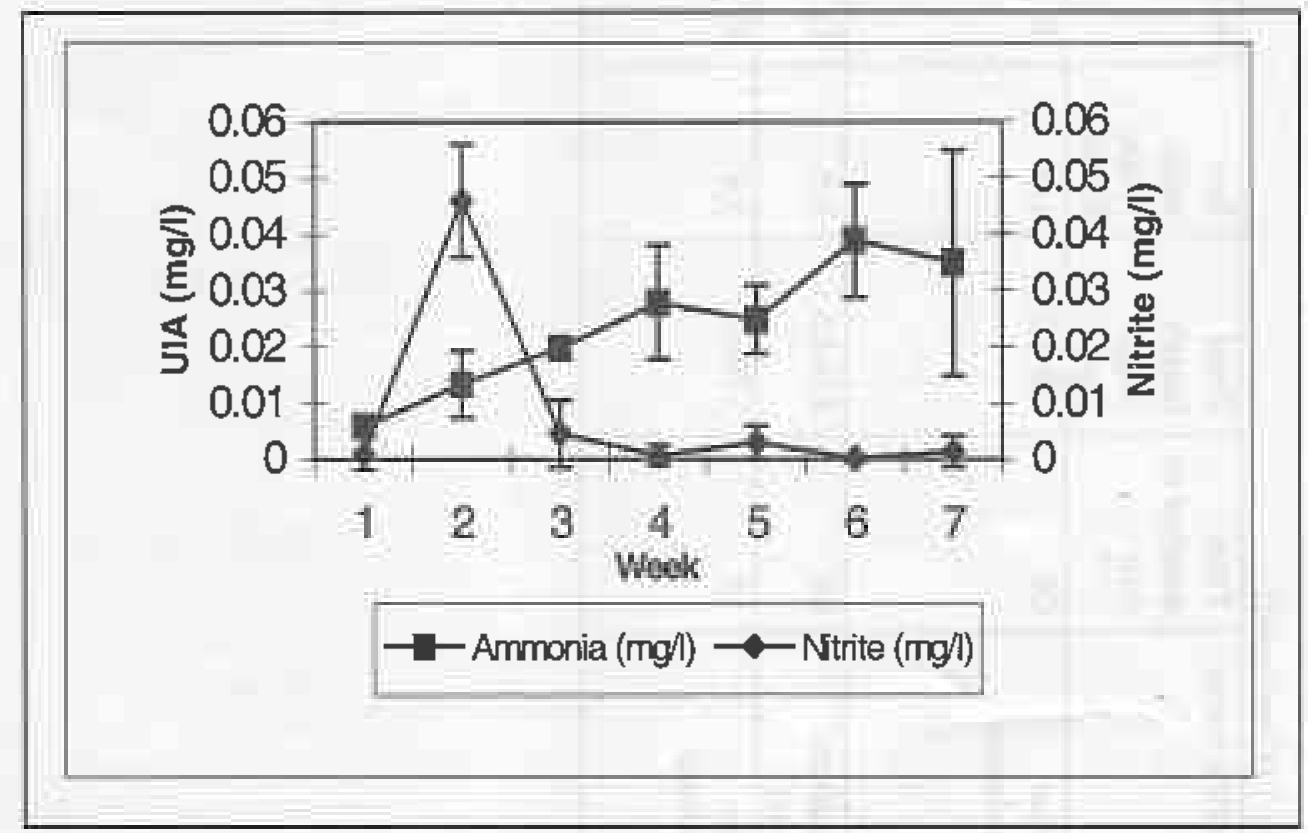

Figure 2. Variation of unionized ammonia (UIA) and nitrite levels in the breeding tanks (vertical bars indicate standard deviation). 
Captive breeding of endemic fish species

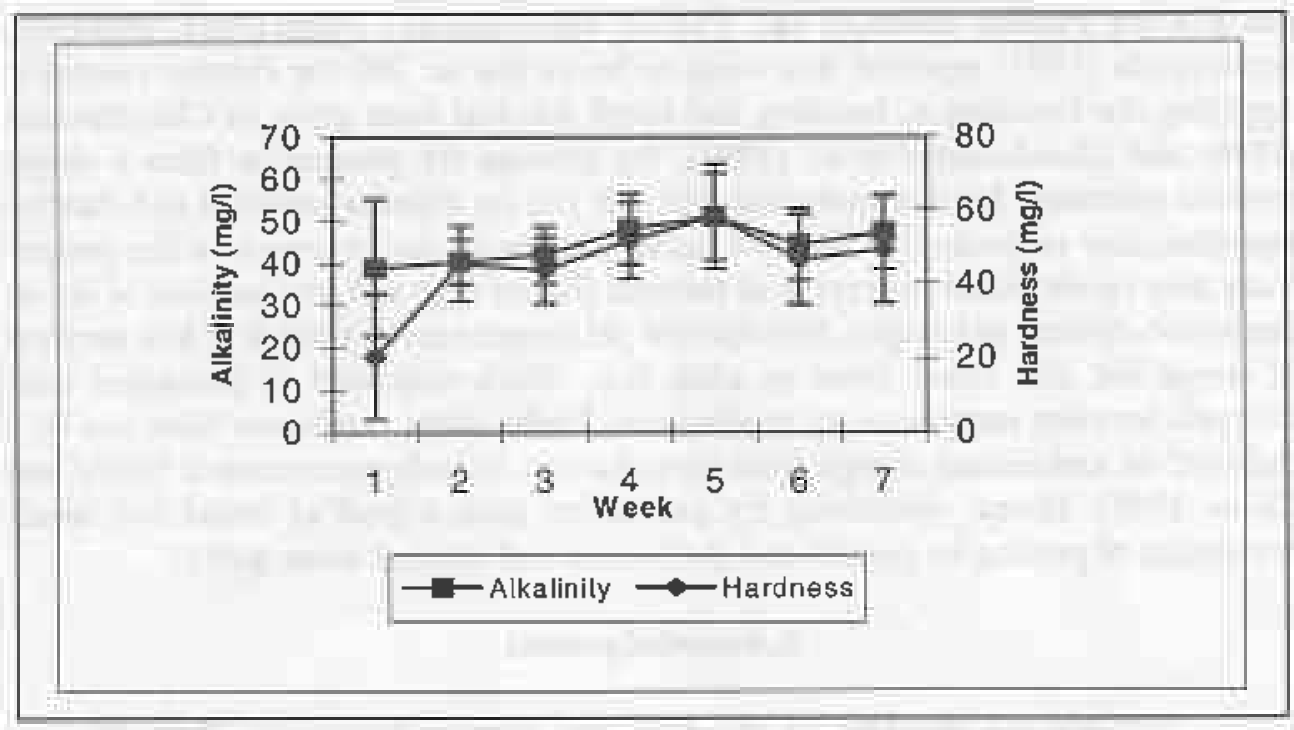

Figure 3. Variation of alkalinity and hardness levels in the breeding tanks (vertical bars indicate standard deviation).

\section{Discussion}

Despite the preference for living in waters with $\mathrm{pH}$ ranging from 5 to 7 , all the experimental endemic ornamental fish were able to breed in captivity in waters with $\mathrm{pH}$ ranging from 7.4 to 9 . The time interval between successive fry production tends to prolong except for Puntius nigrofasciatus and Malpulutta kretseri. Chandrasoma et al. (1994) and Chandrasoma (1996) reported that the average time taken from spawning to rematuration of ovaries to optimum ripeness in Puntius cumingii and Puntius nigrofasciatus female is 9 and 15 weeks, respectively. In the present study, the time intervals observed between successive fry batches were shorter than those reported by of Chandrasoma et al. (1994) and Chandrasoma (1996). However, in the present study, several pairs of brood fish were used in a single tank as opposed to the use of a single pair of parent fish in small glass aquaria by Chandrasoma et al. (1994) and Chandrasoma (1996). Moreover, the present study was designed to study the broodstock management for consistent supply of fry by maintaining a pooled stock of brood fish in order to apply in a commercial venture.

The tendency to prolonging time interval between successive fry production by a broodstock after first 3-4 fry batches indicates the need for frequent broodstock turnovers in a commercial operation and maintenance of large number of backup stocks. The quantity of fry produced in this preliminary study is not impressive for a commercial venture. The optimum number of broodstock and turnover time, however, yet to be determined in order to provide a consistent supply of fry in adequate quantities. Mean number of eggs produced per spawning cycle has been reported by Chandrasoma et al. (1994) and Chandrasoma (1996) to be as high as 507 
and 874 for Puntius cumingii and Puntius nigrofasciatus respectively. However, Pethiyagoda (1991) reported this value to be as low as 100 for Puntius cumingit. Applying the fertilisation, hatching and larval survival rates given in Chandrasoma (1996) and Chandrasoma et al. (1994), the average fry production from a single spawner estimated for this study was 412 and 192 for Puntius cumingii and Puntius nigrofasciatus respectivély. The low survival rates of fry observed in the present study may be attributed to preying of parental fish on eggs and low survival of larvae due to sub-optimal $\mathrm{pH}$ ranges. Sub-optimal $\mathrm{pH}$ ranges not only result in low survival of larvae but also cause stress in adult fish, which may lead to prolonged time intervals between successive fry productions. Under stress conditions there can be a trade-off of assimilated energy from reproduction to body maintenance (Sibly and Calow 1989). Hence, optimising fry production from a pool of brood fish needs prevention of preying by parents and maintenance of optimal water quality.

\section{Acknowledgement}

Authors are thankful to the National Aquatic Resources Research and Development Agency, Colombo 15, Sri Lanka for providing financial assistance and infrastructure facilities for the study.

\section{References}

APHA, 1998

Standard Method for the Examination of Water and Waste Water $20^{\text {th }}$ Edition, American Public Health Association, USA.

Chandrasoma, J. 1996.

Some aspects of reproductive biology and captive breeding of Puntius nigrofasciatus (Cyprinidae), an endemic and endangered species in Sri

Lanka. Sri Lanka Joumal of Aquatic Sciences 1: 103-111

Chandrasoma, J., H.C. Chin. \& H.P. Amandakoon, H.P 1994.

Reproductive biology and breeding of cuming's barb (Puntius cumingii

Gunther) Jounal of Applied Ichthyology, 10: 209-214

Government Gazette 1998.

Export and Import of live fish regulations. Gazette Extraordinary of the IUCN 2000.

Democratic Socialist Republic of Sri Lanka. No. 1036/13

The 1999 list of threatened fauna and flora of Sri Lanka. IUCN Sri Lanka $113 \mathrm{p}$.

Pethiyagoda, R. 1991.

Freshwater Fishes of Sri Lanka, Wildlife Heritage Trust of Sri Lanka, Colombo. 362 p.

Sibly, R.M. \& P. Calow 1989.

A life-cycle theory of response to stress. Biological Journal of Linnean Society 37: 101-106. 
Captive breeding of endemic fish species

Wijeyaratne, M.J.S. 1993.

Conservation of freshwater fish biodiversity in Sri Lanka. Conservation and Sustainable Development, University of Michigan 1: 61-75. 